\title{
Power Generation from Exhaust Gases of Diesel Engines: An Overview and an Approach
}

\author{
Shubham V. Lasankute ${ }^{1}$, Sanket P. Wankhade ${ }^{2}$, Shubham G. Darokar ${ }^{3}$, Rohit R. Dabhade ${ }^{4}$, \\ Prof. Vikramsingh R. Parihar ${ }^{5^{*}}$ \\ U.G Students, Department of Electrical Engineering, PRMCEAM, Amravati, India ${ }^{1,2,3,4}$
}

Assistant Professor, Department of Electrical Engineering, PRMCEAM, Amravati, India ${ }^{5}$

\begin{abstract}
In this research work the modification of stationary diesel engine for producing power using turbine. Nowadays in automobile field many new innovating concepts are being developed. We are using the power from vehicle exhaust to generate the electricity which can be stored in battery for the later consumption. In this project, we are demonstrating a concept of generating power in a stationary single cylinder diesel engine by the usage of turbines. Here we are placing a turbine in the path of exhaust in the silencer. An engine is also placed in the chassis of the vehicle. The turbine is connected to a dynamo, which is used to generate power. Depending upon the airflow the turbine will start rotating, and then the dynamo will also start to rotate. A dynamo is a device which is used to convert the kinetic energy into electrical energy. The generated power is stored to the battery. It can be stored in the battery after rectification. The rectified voltage can be inverted and can be used in various forms of utilities.
\end{abstract}

Keywords: Automotive Engines, Power Generation, Turbines, Diesel Engine, Exhaust Gases, Dynamo

\section{INTRODUCTION}

In recent years the scientific and public awareness on environmental and energy issues has brought in major interests to the research of advanced technologies particularly in highly efficient internal combustion engines. Viewing from the socioeconomic perspective, as the level of energy consumption is directly proportional to the economic development and total number of population in a country, the growing rate of population in the world today indicates that the energy demand is likely to increase. Substantial thermal energy is available from the exhaust gas in modern automotive engines. Two-thirds of the energy from combustion in a vehicle is lost as waste heat, of which $40 \%$ is in the form of hot exhaust gas. The latest developments and technologies on waste heat recovery of exhaust gas from internal combustion engines (ICE). These include thermoelectric generators (TEG), Organic Rankin cycle (ORC), six-stroke cycle IC engine and new developments on turbocharger technology. Being one of the promising new devices for an automotive waste heat recovery, thermoelectric generators (TEG) will become one of the most important and outstanding devices in the future. A thermoelectric power generator is a solid state device that provides direct energy conversion from thermal energy (heat) due to a temperature gradient into electrical energy based on "See beck effect".

The thermoelectric power cycle, charge carriers (electrons) serving as the working fluid, follows the fundamental laws of thermodynamics and intimately resembles the power cycle of a conventional heat engine. One potential solution is the usage of the exhaust waste heat of combustion engines. This is possible by the waste heat recovery using thermoelectric generator. Thermoelectric generator converts the temperature gradient into useful voltage that can used for providing power for auxiliary systems such as air conditioner and minor car electronics. Even it can reduce the size of the alternator that consumes shaft power. If approximately $6 \%$ of exhaust heat could be converted into electrical power, it will save approximately same quantity of driving energy. It will be possible to reduce fuel also. For example, the heat of the car's exhaust can be used to warm the engine coolant to keep the engine running warm, even when the motor has been turned off for a significant length of time. A vehicle's exhaust can actually be used to generate electricity. Although these technologies can be used in any car, truck or SUV with an internal combustion engine, they're particularly important to hybrid vehicles, which need to produce maximum fuel efficiency. 


\section{International Advanced Research Journal in Science, Engineering and Technology}

Vol. 5, Issue 9, September 2018

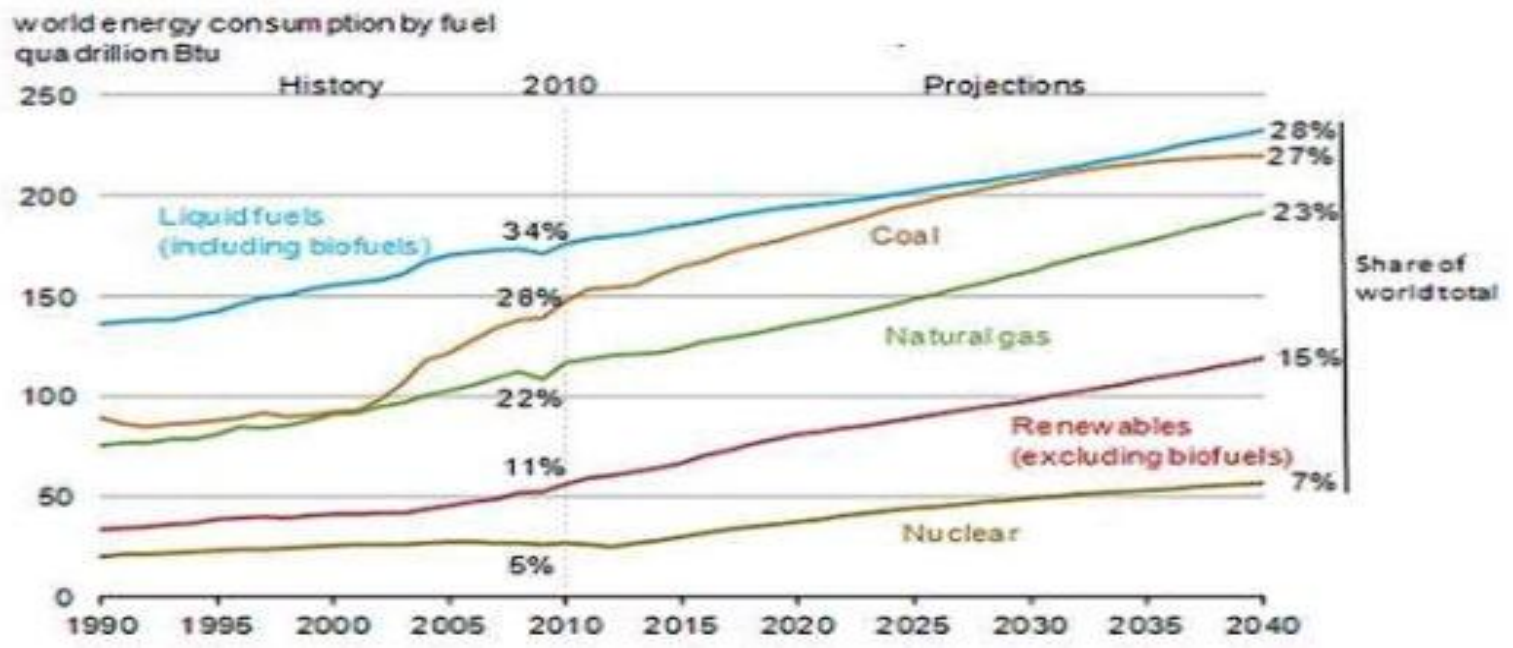

Figure 1. World fuel consumption levels from 1990-2040

Typical Energy Split in Gasoline Internal Combustion Engines

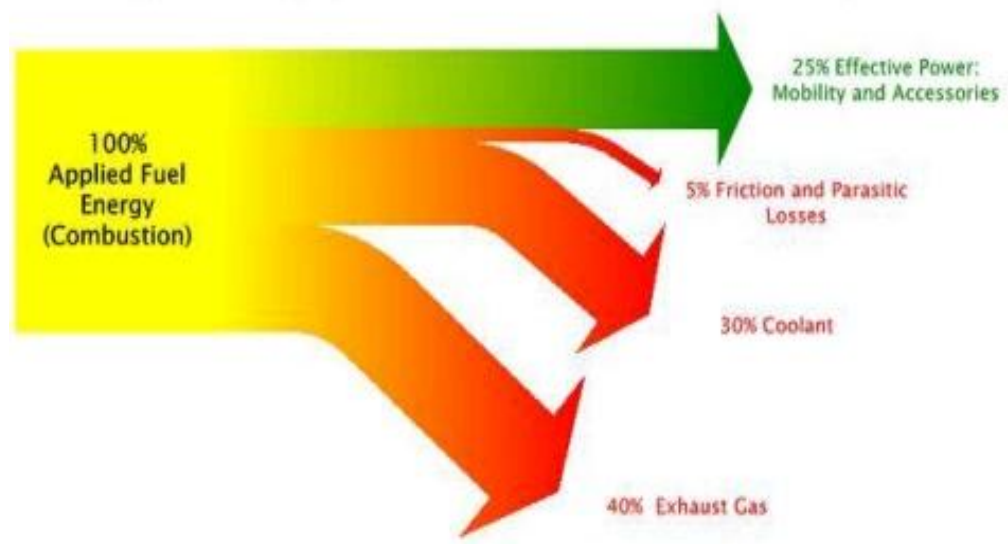

Figure 2. Engine temperature losses.

About $35 \%$ of the fuel is converted to useful crankshaft work, and about $30 \%$ energy is expelled with the exhaust. This leaves about one third of the total energy that must be transmitted from the enclosed cylinder through the cylinder walls ahead to the surrounding atmosphere.

\section{RELATED WORK}

This research works the modification of stationary diesel engine for producing power using turbine. Nowadays in automobile field many new innovating concepts are being developed. We are using the power from vehicle exhaust to generate the electricity which can be stored in battery for the later consumption. In this project, we are demonstrating a concept of generating power in a stationary single cylinder diesel engine by the usage of turbines. Here we are placing a turbine in the path of exhaust in the silencer. An engine is also placed in the chassis of the vehicle. The turbine is connected to a dynamo, which is used to generate power. Depending upon the airflow the turbine will start rotating, and then the dynamo will also starts to rotate. A dynamo is a device which is used to convert the kinetic energy into electrical energy. The generated power is stored to the battery. It can be stored in the battery after rectification. The rectified voltage can be inverted and can be used in various forms of utilities. 


\section{International Advanced Research Journal in Science, Engineering and Technology}

Vol. 5, Issue 9, September 2018

Table 1: Related Work

\begin{tabular}{|c|c|c|c|c|c|c|}
\hline $\begin{array}{l}\text { Sr. } \\
\text { no. }\end{array}$ & $\begin{array}{l}\text { Ref. no. Concerned } \\
\text { Authors and year }\end{array}$ & Concept used & $\begin{array}{l}\text { Performance } \\
\text { evaluation } \\
\text { parameter }\end{array}$ & $\begin{array}{l}\text { Database } \\
\text { used }\end{array}$ & $\begin{array}{l}\text { Claims by concerned } \\
\text { Authors }\end{array}$ & Our finding \\
\hline 1 & $\begin{array}{l}\text { Venkatesh .J, Karthik } \\
\text { Kumar,R Karth ike } \\
\text {.G,Kavin.R, Keerthi raja } \\
\text { (Apr2018) }\end{array}$ & $\begin{array}{l}\text { Electricity } \\
\text { generation from } \\
\text { exhaust hot gases by } \\
\text { using turbine and } \\
\text { dynamo }\end{array}$ & Not mention & $\begin{array}{l}\text { Not } \\
\text { mention }\end{array}$ & $\begin{array}{l}\text { Authors claimed that it is } \\
\text { efficient and low cost } \\
\text { design. }\end{array}$ & $\begin{array}{l}\text { Performance } \\
\text { characteristics are } \\
\text { not given }\end{array}$ \\
\hline 2 & $\begin{array}{l}\text { Priscilla A. J. } \\
\text { Stecanella, Messias A. } \\
\text { Faria, Elder G. } \\
\text { Domingues, Pedro H. G. } \\
\text { Gomes, Wesley P. } \\
\text { Calixto (2015) }\end{array}$ & $\begin{array}{l}\text { Electricity } \\
\text { generation from } \\
\text { exhaust hot gases by } \\
\text { using turbine and } \\
\text { dynamo }\end{array}$ & Not mention & $\begin{array}{l}\text { Not } \\
\text { mention }\end{array}$ & $\begin{array}{l}\text { The authors observed that } \\
\text { the residual thermal } \\
\text { energy can be used as } \\
\text { electricity generation by } \\
\text { using TEG. }\end{array}$ & $\begin{array}{l}\text { Performance } \\
\text { characteristics are } \\
\text { not given }\end{array}$ \\
\hline 3 & $\begin{array}{l}\text { Shaikh Mobin A.,Shaikh } \\
\text { Saif A., Shaikh Najim } \\
\text { N., Pathan Umar Farooq } \\
\text { O.,Pathan Farhan A } \\
\text { (march 2017) }\end{array}$ & $\begin{array}{l}\text { power generation } \\
\text { from exhaust hot } \\
\text { gases by using } \\
\text { turbine bearing gear } \\
\text { system \& dynamo }\end{array}$ & $\begin{array}{l}\text { Power obtained } \\
\text { at a turbine } \\
\text { speed of } 400 \\
\text { rpm. Is } 1.701 \mathrm{~W}\end{array}$ & $\begin{array}{l}\text { Not } \\
\text { mention }\end{array}$ & $\begin{array}{l}\text { Authors claimed that by } \\
\text { using this system fuel } \\
\text { economy is saved up to } \\
\text { greater extent. }\end{array}$ & $\begin{array}{l}\text { By using this } \\
\text { system power } \\
\text { generation is very } \\
\text { less }\end{array}$ \\
\hline 4 & $\begin{array}{l}\text { Kranthi Kumar } \\
\text { Guduru,Yakoob Kol } \\
\text { ipak, Shanker. B, N. } \\
\text { Suresh (Dec 2015) }\end{array}$ & $\begin{array}{l}\text { Electricity } \\
\text { generation from } \\
\text { exhaust hot gases by } \\
\text { using turbine and } \\
\text { dynamo. }\end{array}$ & $\begin{array}{l}\text { Maximum } \\
\text { voltage } 24 \text { volts } \\
\text { is obtained at a } \\
\text { Engine speed of } \\
1500 \mathrm{rpm}\end{array}$ & $\begin{array}{l}\text { Not } \\
\text { mention }\end{array}$ & $\begin{array}{l}\text { Authors claimed that } \\
\text { waste heat can be used to } \\
\text { generate effective } \\
\text { electricity generation. }\end{array}$ & $\begin{array}{l}\text { Project diagram/ } \\
\text { block diagram is } \\
\text { not given }\end{array}$ \\
\hline 5 & $\begin{array}{l}\text { Rupesh Suryavanshi, } \\
\text { Prof.A.D.Pitale ( Apr } \\
\text { 2017) }\end{array}$ & $\begin{array}{l}\text { Waste heat recovery } \\
\text { for improving } \\
\text { efficiency of the } \\
\text { vehicle }\end{array}$ & Not mention & $\begin{array}{l}\text { Not } \\
\text { mention }\end{array}$ & $\begin{array}{l}\text { Waste exhaust gas can be } \\
\text { used for power } \\
\text { generation. }\end{array}$ & $\begin{array}{l}\text { Performance } \\
\text { characteristics are } \\
\text { not given }\end{array}$ \\
\hline 6 & $\begin{array}{l}\text { S.Vijaya Kumar,Amit } \\
\text { Kumar Singh,Athul } \\
\text { Sabu, Mohamed } \\
\text { Farhan.P (May 2015) }\end{array}$ & $\begin{array}{l}\text { Power generation } \\
\text { from exhaust gases }\end{array}$ & $\begin{array}{l}\text { Maximum power } \\
\text { i.e. }(15 \mathrm{~W}) \text { is } \\
\text { obtained at speed } \\
\text { of } 3970 \mathrm{rpm}\end{array}$ & $\begin{array}{l}\text { Not } \\
\text { mention }\end{array}$ & $\begin{array}{l}\text { Authors claimed that } \\
\text { Large potentials of } \\
\text { energy is saved by using } \\
\text { this technology }\end{array}$ & Good performance \\
\hline
\end{tabular}

\section{III.PROBLEM FORMULATION}

This chapter presents the formulation of the identified problem, which based representation of a power generation from exhaust hot gases by diesel engine All the reviews on theoretic approaches involve the same common terminologies. In our day to day life the population is increased that will result in increasing the no. of vehicle. On that vehicles $1 / 3$ rd of energy is totally wastage by exhauster from this wastage of hot gases we can convert it into the electrical energy by giving a suitable arrangement.

\section{IV.PROPOSED APPROACH}

Section 4.1 includes the information about the main components used This chapter is subdivided into 4 sections wherein the report presents the detailed working of power generation from exhaust hot gases by diesel engine that is incorporated in our work along with our approach. In this project. 4.2. Working of system is explained. 4.3 Flowchart 4.4 this section gives the application by using this system

\subsection{MAIN COMPONENTS}

\section{A) Nozzle}

Nozzle is attached to the Silencer of the vehicle for the proper flow of exhaust gases with high velocity and steady flow with uniform direction to rotate the turbine.

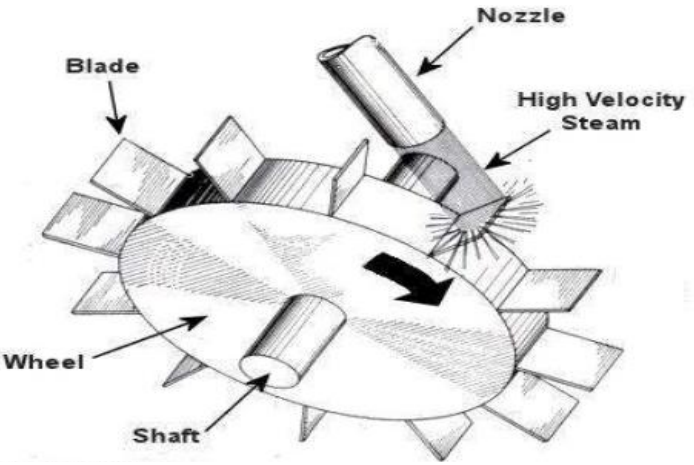

Figure 1. Nozzle 


\section{International Advanced Research Journal in Science, Engineering and Technology}

Vol. 5, Issue 9, September 2018

Therefore, when calling mobile calls, that buzzer is heard indicating the valve needs to be open. By pressing the button in the called function, the signal is given back to the microcontroller. The microcontroller gives signal to the valves which causes it to get open. The water is given to the root of the plant drop by drop, and when the moisture content becomes sufficient, the sensor senses this and gives back the signal to the microcontroller and the buzzer becomes off. Then by pressing the button in the calling function again, the valve is made off. The power supply needed by the controlling system is $+5 \mathrm{~V}$. The entire unit is as shown in Fig.2.

\section{B) Turbine}

A Steam turbine is a mechanical device that extracts thermal energy from pressurized steam, and converts it into rotary motion. It has almost completely replaced the reciprocating piston steam engine primarily because of its greater thermal efficiency and higher power-to-weight ratio. Because the turbine generates rotary motion, it is particularly suited to be used to drive an electrical generator - about $90 \%$ of all electricity generation in the United States is by use of steam turbines. The steam turbine is a form of heat engine that derives much of its improvement in thermodynamic efficiency through the use of multiple stages in the expansion of the steam, which results in a closer approach to the ideal reversible process.

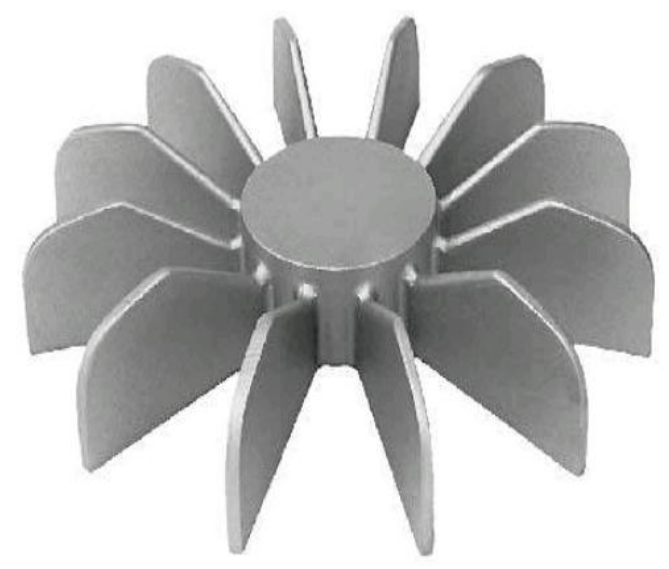

Figure 2. Turbine

\section{C) Dynamo}

Dynamo is an electrical generator. This dynamo produces direct current with the use of a commutator. Dynamos were the first generator capable of the power industries. The dynamo uses rotating coils of wire and magnetic fields to convert mechanical rotation into a pulsing direct electric current. A dynamo machine consists of a stationary structure, called the stator, which provides a constant magnetic field, and a set of rotating windings called the armature which turn within that field. On small machines the constant magnetic field may be provided by one or more permanent magnets, larger machines have the constant magnetic field provided by one or more electromagnets, which are usually called field coils.

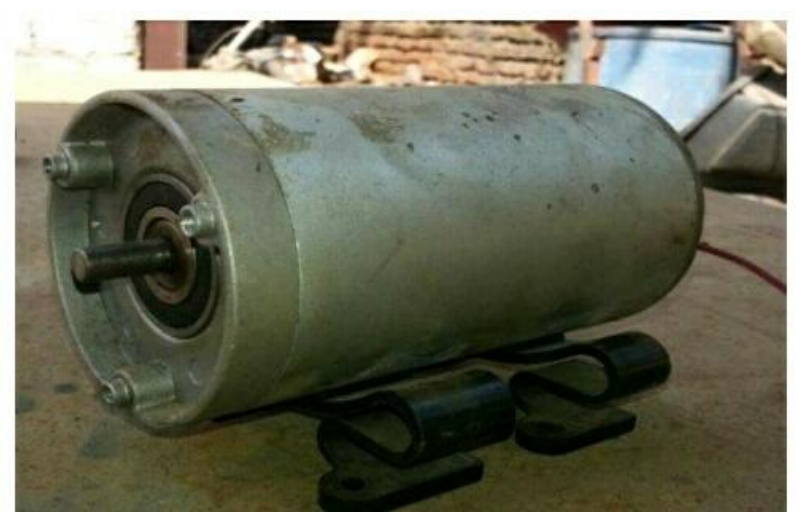

\section{D) Battery}

Figure 3. Dynamo

There are many types of batteries are used Lead acid, lithium fluoride and in this work $8 \mathrm{~A} t$ is a device user to store the power. The power is stored in the form of DC current only. The current and 12 voltage specification is used. 


\section{International Advanced Research Journal in Science, Engineering and Technology}

Vol. 5, Issue 9, September 2018

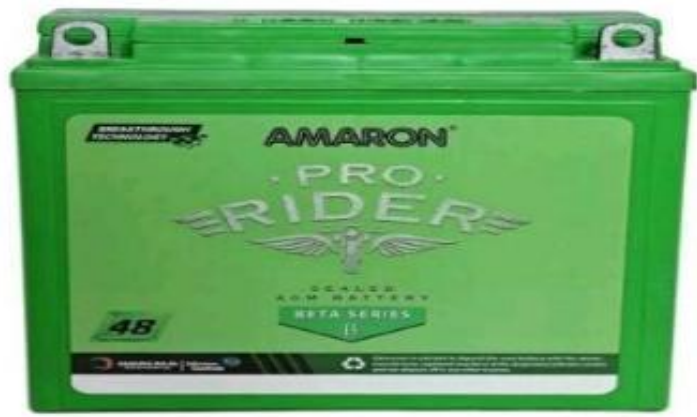

Figure 4. Battery

\subsection{Working}

Power is generated by using automobile exhaust gas is very simple and easy non-conventional process. Energy generation using vehicle silencer needs no fuel input power to generate the output of the electrical power. This project using simple mechanism same as wind energy power generation. For this project the main Working Principle is Conversion of the forced kinetic energy into electrical energy. In this the exhaust gases released from the automobile Silencer is used to rotate the turbine (fan blades) by arranging it is very conveniently. The nozzle is attached to the silencer is used to proper flow of exhaust gases with high velocity and steady flow with uniform direction to rotate the turbine. The dynamo attached to the turbine with shaft is used to convert the forced kinetic energy (K.E) into electrical energy (E.E) is by rotating dynamo

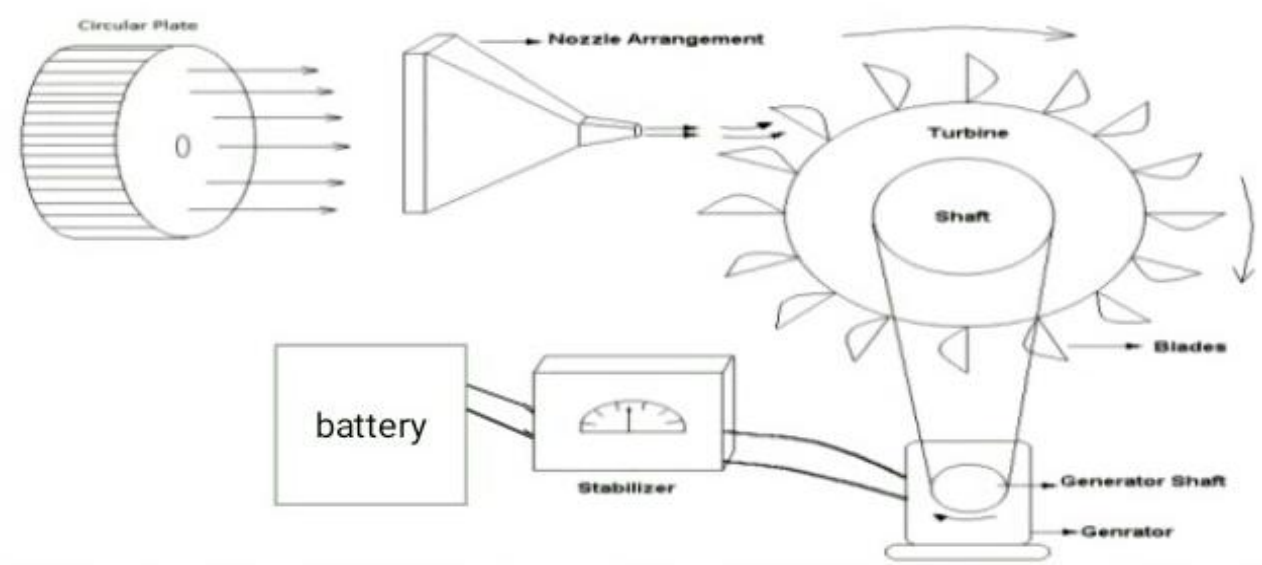

Figure 5. General Layout of Electricity Generation from Exhaust Hot Gases

\subsection{Flowchart}

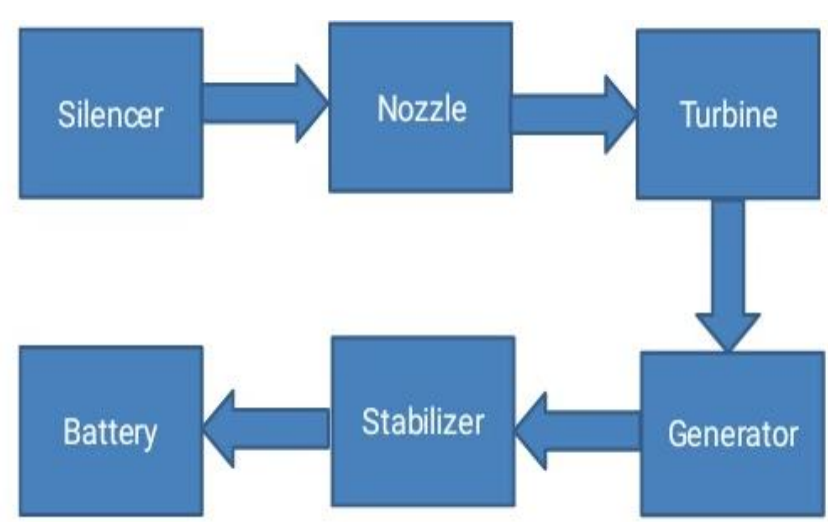

Figure 6. Flowchart of the working 


\section{International Advanced Research Journal in Science, Engineering and Technology}

Vol. 5, Issue 9, September 2018

\subsection{Application}

- $\quad$ It is applicable for all stationary and moving vehicles.

- $\quad$ It is applicable for all Automobiles.

- $\quad$ The generating power is applicable for house hold

- Uses like indicators, horn etc.

- $\quad$ No problems of discharge in the batteries.

- It is a simple non - conventional energy process.

- $\quad$ Generating power can reduce the need of power.

- $\quad$ To generate the power no need of fuel input

\section{CONCLuSION}

Irrigation has been the backbone of human civilization since man has started agriculture. As the generation evolved, man developed many methods of irrigation to supply water to the land. In the present scenario on conservation of water is of high importance. Present work is attempts to save the natural resources available for human kind. Out of the various systems of automatic irrigation, the GSM based irrigation have found to have better applications as it avoids over irrigation, under irrigation, top soil erosion and reduce the wastage of water. The main advantage is that the system's action can be changed according to the situation (crops, weather conditions, soil etc.).

By implementing this system, agricultural, horticultural lands, parks, gardens, golf courses can be irrigated. Thus, this system is cheaper and efficient when compared to other type of automation system. In large scale applications, high sensitivity sensors can be implemented for large areas of agricultural lands. A stand by battery or solar cells can be implemented which comes into use in case of power cuts. A secondary pump can be used in case of failure of the pump.

\section{VI.EXPERIMENTAL RESULTS \& DISCUSSION}

From the figure 7 , the highest break power value $(10.30 \mathrm{KW})$ is obtained at the load 1500 watts at the constant engine speed is 1500 revolutions per minute (r.p.m).

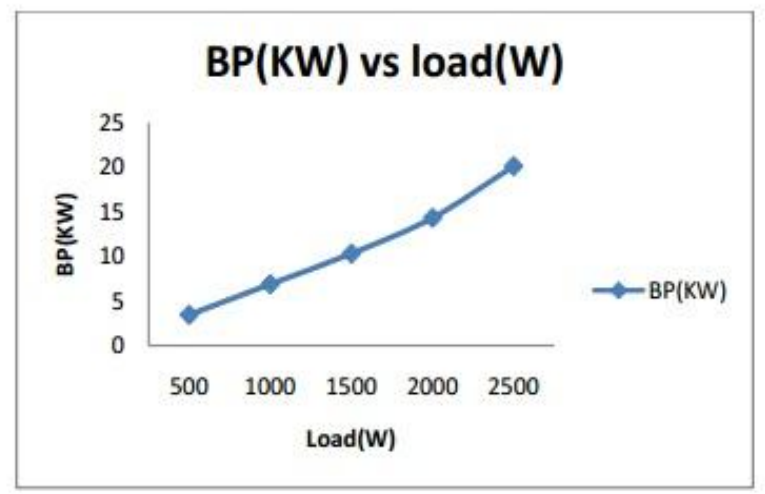

Figure 7. Plotted for Break power (KW) of engine to Load on Engine (W)

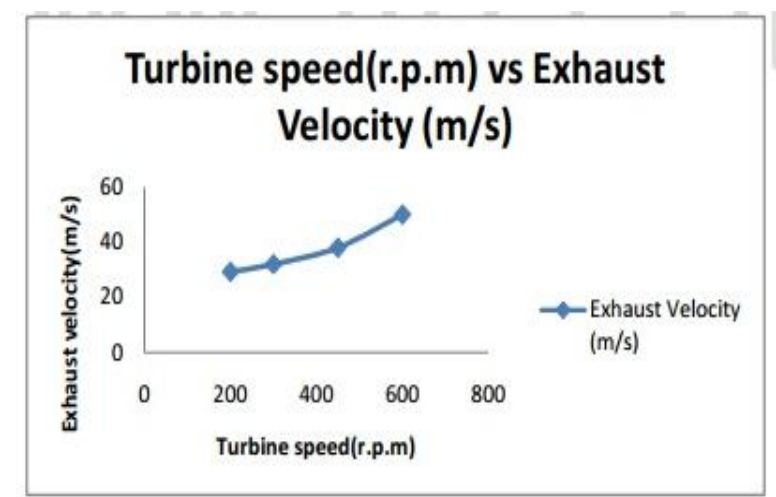

Figure 8. Plotted for turbine speed (r. p. m) to exhaust velocity (m/s) 


\section{International Advanced Research Journal in Science, Engineering and Technology}

Vol. 5, Issue 9, September 2018

From the figure 8 , the turbine speed at the 600 r. p. m the exhaust velocity is $50 \mathrm{~m} / \mathrm{s}$ at the constant engine speed is 1500 revolutions per minute (r. p. m).

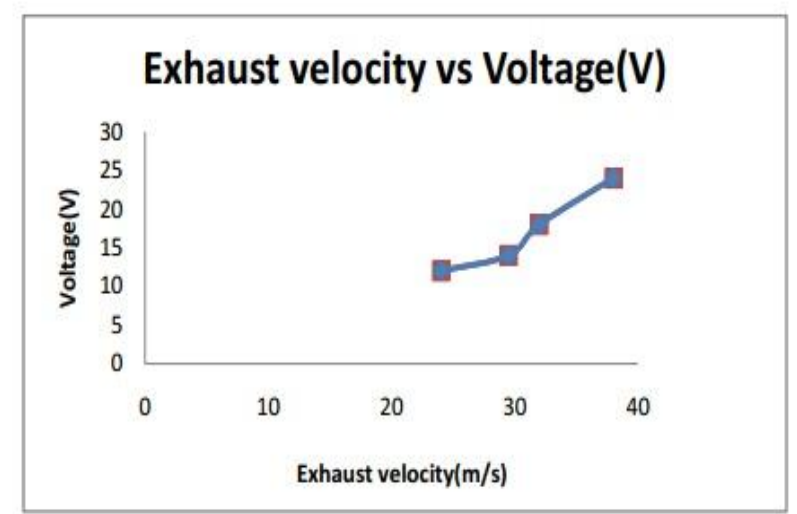

Figure 9. Plotted for voltage (V) generated from the exhaust velocity $(\mathrm{m} / \mathrm{s})$

From the figure 9 , it is observed that the maximum voltage (24 volts) is obtained at exhaust velocity $38 \mathrm{~m} / \mathrm{s}$ at the engine speed 1500 r. p. m.

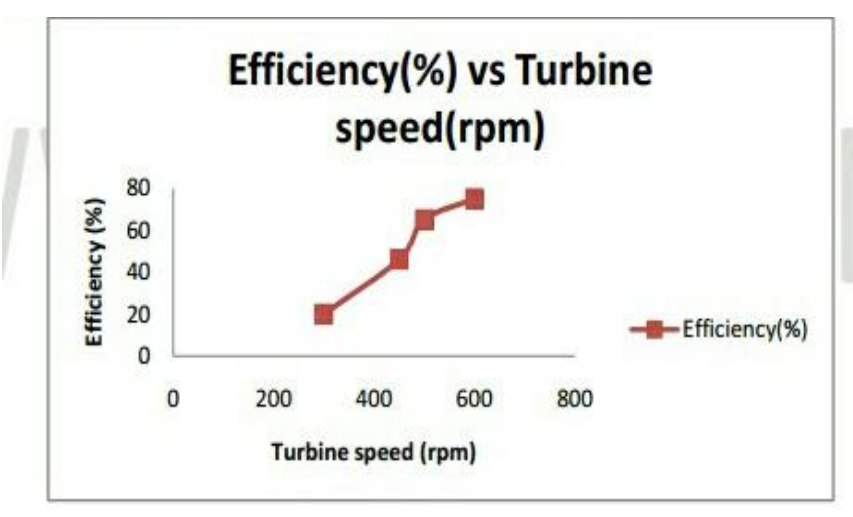

Figure 10. Plotted for efficiency to the turbine speed (r. p. m)

\section{CONCLUSION AND FUTURE SCOPE}

From the study, it has been identified that there are large potentials of energy savings through the use of waste heat recovery technologies. Waste heat recovery entails capturing and reusing the waste heat from internal combustion engine and using it for heating or generating mechanical or electrical work. It would also help to recognize the improvement in performance and emissions of the engine if these technologies were adopted by the automotive manufacturers. The study also identified the potentials of the technologies when incorporated with other devices to maximize potential energy efficiency of the vehicles. The project carried out by us made an impressing task in the field of mechanical department. It is used for to produce the current in vehicle exhaust unit.

\subsection{Future Scope}

Power Generation Using Exhaust Gases $\|$ is mainly intended to design a silencer based energy generation system based inverter. Air blowers generally use centrifugal force to propel air forward. Inside a centrifugal air blower is a wheel with small blades on the circumference and a casing to direct the flow of air into the centre of the wheel and out toward the edge. The design of the blades will affect how the air is propelled and how efficient the air blower is. The paper makes use of a Silencer Setup, turbine and DC Generator. The energy obtained is stored to a battery. The battery supply is fed to pulse generator and in turn to a MOSFET which is capable of generating ON/OFF pulses of different frequencies. This is fed to a step up transformer to generate a low voltage AC. This AC is fed to electrical appliance. 


\title{
International Advanced Research Journal in Science, Engineering and Technology
}

\author{
Vol. 5, Issue 9, September 2018
}

\section{REFERENCES}

[1] M. S. Triantafyllou and G. S. Triantafyllou, "An efficient swimming vehicle". Guo, T. Fukuda, and K. Asaka, "A new type of fish-like underwater microrobot," IEEE/ASME Trans. Mechatron., vol. 8, no. 1, pp. 136-141, Mar. 2003.

[2] W. S. N. Trimmer and K. J. Gabriel, "Design considerations for a practical electrostatic micro-motor," Sens. Actuators, vol. 11, no. 2, pp. 126173, Jan. 1987.

[3] T. Schaub, "Spread frequency shift keying", IEEE Trans. Commun., vol. 42, no. 4,pp. 182-296, Aug. 1993.

[4] Brown J. A., "vacuum tanker for cleaning storage tanks," Process Engineering, vol. 21, no. 5, pp.138-180,Sep. 1989

[5] Dr. R. K. Bansal, "Kinematics of machine", Laxmi Publications (P) Ltd ., vol. 1, no. 4, pp. 23-287,Nov. 2011.

[6] Shubham Shrivastav, Hari Om Kumar, "Design and Development of Cylindrical Water tank cleaner", IEEE Trans. Commun.,vol. 6, no. 1, pp. 1-7,Feb. 2016.

[7] Prayosha innovative, "Sedimclean water tank cleaning machine", Prayosha innovative, vol. 1 no. 1, pp.1-177,Feb. 2017.

[8] Shubham Shrivastav, Hari Om Kumar, "Design and Development of Cylindrical Water tank cleaner" ,IEEE Trans. Commun.,vol. 4, no. 8, pp. 1-7,Nov. 2016.Mr. Sankaran Nampoothiri , Ms. Dhanya G2,A Review on Flying Electric Generator as an Alternate Source of Energy Harvester,irjet ,Volume: 03 pp 143-214,04 Apr-2016

[9] Vikramsingh R. Parihar, Graph Theory Based Approach for Image Segmentation Using Wavelet Transform, International Journal of Image Processing (IJIP), Volume 8, Issue 5, pp 255-277, Sept 2014

[10] Vikramsingh R. Parihar, Heartbeat and Temperature Monitoring System for Remote Patients using Arduino, International Journal of Advanced Engineering Research and Science (IJAERS), Volume 4, Issue 5, PP 55-58, May 2017

[11] Vikramsingh R. Parihar, PC Controlled Electrical Line Cutting System, International Journal of Engineering Science and Computing (IJESC), Volume 7, Issue 5, pp 11380-11381, May 2017

[12] Vikramsingh R. Parihar, Overview and an Approach to Develop a Four Quadrant Control System for DC Motors without using Microcontroller, International Journal of Engineering Science and Computing (IJESC), Volume 7, Issue 5, pp 11879-11881, May 2017

[13] Vikramsingh R. Parihar, Image Analysis and Image Mining Techniques: A Review, Journal of Image Processing and Artificial Intelligence (MAT Journals), June 2017

[14] Vikramsingh R. Parihar, Power Transformer Protection using Fuzzy Logic based Controller, International Journal of Engineering Research (IJER), Volume 6, Issue 7, pp 366-370, July 2017

[15] Vikramsingh R. Parihar, Overview and an Approach to Real Time Face Detection and Recognition, International Advanced Research Journal in Science, Engineering and Technology (IARJSET), Volume 4, Issue 9, PP 39-46, Sept 2017

[16] Vikramsingh R. Parihar, Neural Network and Fuzzy Logic Based Controller For Transformer Protection, International Journal of Current Engineering and Scientific Research (IJCESR), Volume 4, Issue 9, PP 33-38, Sept 2017

[17] Vikramsingh R. Parihar, A Novel Approach to Power Transformer Fault Protection using Artificial Neural Network, International Journal of Current Engineering and Scientific Research (IJCESR), Volume 4, Issue 9, PP 33-38, Sept 2017

[18] Vikramsingh R. Parihar, Power Transformer Fault Protection using Artificial Neural Network, Journal of Electrical and Power System Engineering (MAT Journals), Volume 3, Issue 3, pp 1-5, Sept 2017

[19] Vikramsingh R. Parihar, Fuzzy Logic based Controller for Power Transformer Protection, Journal of Electrical and Power System Engineering (MAT Journals), Volume 3, Issue 3, pp 1-5, Oct 2017

[20] Vikramsingh R. Parihar, Real Time Face Detection and Recognition: Overview and Suggested Approach, Journal of Image Processing and Artificial Intelligence (MAT Journals), Volume 3, Issue 3, pp 1-6, Sept 2017

[21] Vikramsingh R. Parihar, A Novel Approach to Real Time Face Detection and Recognition, International Journal of Computer Sciences and Engineering (IJCSE), Volume 5, Issue 9, pp 62-67, Sept 2017

[22] Vikramsingh R. Parihar, Automatic Irrigation System Using Android Mobile: A Review, International Journal of Advanced Research in Computer and Communication Engineering (IJARCCE), Volume 6, Issue 9, pp 200-203, Oct 2017

[23] Vikramsingh R. Parihar, Transmission Line Multiple Fault Detection: A Review and an Approach, International Journal of Current Engineering and Scientific Research (IJCESR), Volume 4, Issue 10 pp 1-7, Oct 2017

[24] Vikramsingh R. Parihar, Regenerative Braking System for Energy Harvesting from Railways and Vehicles: A Review and an Approach, International Journal of Innovative Research in Electrical, Electronics, Instrumentation and Control Engineering (IJIREEICE), Volume 5, Issue 10, pp 18-25, Oct 2017

[25] Vikramsingh R. Parihar, RFID Based Student Attendance Management System: A Review and an Approach, International Advanced Research Journal in Science, Engineering and Technology (IARJSET), Volume 4, Issue 9, pp 262-265, Sept 2017

[26] Vikramsingh R. Parihar, Distance Protection Problem in Series-Compensated Transmission Lines, International Journal of Advanced Trends in Technology, Management and Applied Science (IJATTMAS), Volume 3, Issue 10, pp 44-48, Oct 2017

[27] Vikramsingh R. Parihar, Series-Compensated Transmission Line Problem in Distance Protection, International Journal of Electrical, Electronics and Communication Engineering (IJEECE), Volume 3, Issue 10, pp 1-9, Oct 2017

[28] Vikramsingh R. Parihar, Series Compensated Line Protection using Artificial Neural Network, International Advanced Research Journal in Science, Engineering and Technology (IARJSET), Volume 4, Issue 10, pp 102-111, Oct 2017

[29] Vikramsingh R. Parihar, Protection Scheme of Fault Detection in High Voltage Transmission Line, International Journal of Advanced Trends in Technology, Management and Applied Science (IJATTMAS), Volume 3, Issue 11, pp 1-4, Nov 2017

[30] Vikramsingh R. Parihar, IOT Based Communication Technology for High Voltage Transmission System, Journal of Electrical and Power System Engineering (MAT Journals), Volume 3, Issue 3, pp 1-6, Nov 2017

[31] Vikramsingh R. Parihar, Transmission Line Protection Analysis using STATCOM, International Journal of Advanced Trends in Technology, Management and Applied Science (IJATTMAS), Volume 3, Issue 11, pp 23-26, Nov 2017

[32] Vikramsingh R. Parihar, A Review on Transmission Line Fault Detection Techniques, International Journal of Advanced Trends in Technology, Management and Applied Science (IJATTMAS), Volume 3, Issue 11, pp 27-32, Nov 2017

[33] Vikramsingh R. Parihar, Transmission Line Protection using Distance Relays, International Journal of Electrical, Electronics and Communication Engineering (IJEECE), Volume 3, Issue 1, pp 1-15, Nov 2017

[34] Vikramsingh R. Parihar, Protection of Power Transformers using Artificial Neural Network and Fuzzy logic, International Journal of Advanced Trends in Technology, Management and Applied Science (IJATTMAS), Volume 3, Issue 11, pp 72-79, Nov 2017

[35] Vikramsingh R. Parihar, Control System Security: An Issue, Journal of Control System and Control Instrumentation (MAT Journals), Volume 3, Issue 3, pp 1-5, Dec 2017

[36] Vikramsingh R. Parihar, Resilient Designs of Control Systems Analysis and Review, Journal of Control System and Control Instrumentation (MAT Journals), Volume 3, Issue 3, pp 1-9, Dec 2017 


\title{
International Advanced Research Journal in Science, Engineering and Technology
}

\author{
Vol. 5, Issue 9, September 2018
}

[37] Vikramsingh R. Parihar, Industrial Control System Cyber Security: Review \& Recommendations, Journal of Network Security Computer Networks (MAT Journals), Volume 3, Issue 3, pp 1-9, Dec 2017

[38] Vikramsingh R. Parihar, Operational Analysis of Infrared Gas Sensor, Journal of Instrumentation and Innovation Sciences (MAT Journals), Volume 4, Issue 1, pp 1-5, Dec 2017

[39] Vikramsingh R. Parihar, Automatic Fault Detection in Transmission Lines using GSM Technology, International Journal of Innovative Research in Electrical, Electronics, Instrumentation and Control Engineering (IJIREEICE), Volume 6, Issue 4, pp 90-95, April 2018

[40] Vikramsingh R. Parihar, UPFC based distance relays for protection of transmission systems employing FACTS, International Journal of Advanced Engineering and Technology (IJAET), Volume 2, Issue 2, pp 4-7, May 2018

[41] Vikramsingh R. Parihar, Power Substation Protection from Lightening Over voltages and Power Surges, International Journal of Innovative Research in Electrical, Electronics, Instrumentation and Control Engineering (IJIREEICE), Volume 6, Issue 6, pp 26-31, June 2018

[42] Vikramsingh R. Parihar, An Overview of Transmission Line Fault Detection Techniques, International Journal of Innovative Research \& Studies (IJIRS), Volume 8, Issue VII, pp 64-77, July-2018

[43] Vikramsingh R. Parihar, Power Monitoring System Using Microcontroller for Optimum Power Utility in homes, Reinvention International: An International Journal of Thesis Projects and Dissertation, Volume 1, Issue 1, pp 96-112, Aug-2018

[44] Vikramsingh R. Parihar, Automatic Wireless Health Monitoring System, Reinvention International: An International Journal of Thesis Projects and Dissertation, Volume 1, Issue 1, pp 84-95, Aug-2019

[45] Vikramsingh R. Parihar, Overview and an Approach for QR-Code Based Messaging and File Sharing on Android Platform in View of Security, Proceedings of the IEEE 2017 International Conference on Computing Methodologies and Communication (ICCMC), July 2017

[46] Vikramsingh R. Parihar, Line Trap and Artificial Intelligence Based Double Circuit Transmission Line Fault Classification, International Conference on Energy, Communication, Data Analytics and Soft Computing (ICECDS 2017), August 2017

[47] Vikramsingh R. Parihar, Hybrid Power System with Integration of Wind, Battery and Solar PV System, IEEE International Conference on Power, Control, System and Instrumentation Engineering (ICPCSI), Sept 2017

[48] Vikramsingh R. Parihar, A Novel System of Real Time Hand Tracking and Gesture Recognition, IEEE International Conference on Inventive Computing and Informatics (ICICI), Nov 2017.

[49] Vikramsingh R. Parihar, Improving Power Quality of Induction Motors using Capacitor Bank, International Journal of Innovative Research in Electrical, Electronics, Instrumentation and Control Engineering (IJIREEICE), Volume 6, Issue 9, pp 37-45, Sept 2018

\section{BIOGRAPHY}

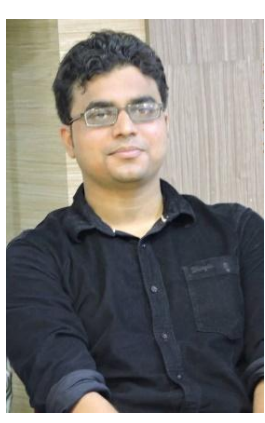

Prof. Vikramsingh R. Parihar is an Assistant Professor in Electrical Department, PRMCEAM, Badnera-Amravati having 7 years of experience. He has received the B.E degree in Instrumentation from Sant Gadge Baba Amravati University, India, in 2011 and the M.E degree in Electrical and Electronics Engineering, Sant Gadge Baba Amravati University, India, in 2014. He is editorial board member of 25 recognized journals and life member of CSTA, ISTE, HKSME, ICSES, IJCSE, theIRED Engineering New Zealand and IAENG. His domain of research includes Electrical Engineering, Instrumentation, Electrical Power Systems, Electrical and Electronics Engineering, Digital Image Processing, Neuro Fuzzy Systems and has contributed to research in a commendable way by publishing 45 research papers in National/International Journals including 4 papers in IEEE Conferences. 